\title{
The development and implementation of a real-time meteotsunami warning network for the Adriatic Sea
}

\author{
J. Šepić and I. Vilibić \\ Institute of Oceanography and Fisheries, Split, Croatia \\ Received: 27 August 2010 - Revised: 15 October 2010 - Accepted: 28 October 2010 - Published: 5 January 2011
}

\begin{abstract}
The Adriatic Sea meteotsunami research and warning network is described. The network is located in the middle Adriatic, an area where the most destructive of the Adriatic meteotsunamis (destructive tsunami-like sea level oscillations generated by air pressure oscillations) occur. The network consists of three microbarograph meteorological stations, and is supplemented by four permanent tidegauge stations. The two strongest air pressure disturbances, detected in almost a year and a half of measurements, are examined in more detail and used to test functionality and applicability of the network. Both of these disturbances had a meteotsunami favourable velocity, however, only one generated a meteotsunami. It is discussed why this happened and additional information on creating a meteotsunami warning system are obtained. Methods to construct a simple low-cost meteotsunami warning network are given.
\end{abstract}

\section{Introduction}

Devastating tsunamis causing severe damage end even greater human loss are well known (e.g., Lay et al., 2005). Due to their number and destructivity, highly efficient warning systems have been created for the endangered coastal areas (e.g., Meinig et al., 2005; Titov et al., 2005). However, there is another kind of a tsunami-like danger that has not been so extensively researched and for which there is yet no reliable operational warning system: meteorological tsunamis (Monserrat et al., 2006). These are tsunamilike disastrous sea waves generated by atmospheric activity, in particular, air pressure fluctuations. Meteotsunamis are known to cause extensive damage and even loss of human life. The Balearic Island meteotsunami of 15 June 2006 with $5 \mathrm{~m}$ high waves caused economic loss of several tens of

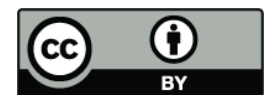

Correspondence to: J. Šepić (sepic@izor.hr) millions of euros (Jansa et al., 2007; Vilibić et al., 2008). The Nagasaki Bay meteotsunami of 31 March 1979, again with $5 \mathrm{~m}$ high waves, resulted in the drowning of three elderly women (Hibiya and Kajiura, 1982). Meteorological tsunamis also occur at other highly populated coastal areas, e.g., the United Kingdom (Haslett et al., 2009), east of the China Sea coast (in particular Langkou Harbour, Wang et al., 1987), British Columbia (Thomson et al., 2009), the United States (Paxton and Sobien, 1998), and other places (Monserrat et al., 2006).

Although differing from tsunamis by their origin, and method of propagation, meteotsunamis are often mistaken for tsunamis. The $6 \mathrm{~m}$ high tsunami-like waves which hit Vela Luka in the Adriatic Sea on the 21 June 1979 (Hodžić, 1979/1980) and which caused 7 million US dollar damage at that time (equaling a quarter of the annual income of the whole Korčula Island municipality) were first assumed to be a tsunami generated by an earthquake in the Aegean Sea (Zore-Armanda, 1979), or by a landslide in the Adriatic Sea (Bedosti, 1980), and are even listed in the catalogue of Adriatic tsunamis as the second strongest observed tsunami (Tinti et al., 2004). However, recent studies based of numerical modelling and a fresh look at the data classifies the event as a meteotsunami (Vučetić et al., 2009; Orlić et al., 2010). Likewise, a recent tsunami-like sea level oscillation in the Black Sea was first recognized as a land-slide induced tsunami (Ranguelov et al., 2008) but a subsequent analysis showed that it is most likely a meteorological tsunami (Vilibić et al., 2010).

Due to their relation with atmospheric processes and in particular with air pressure disturbances, meteorological tsunamis could presumably be forecasted more easily and at a lower cost than tsunamis. Meteorological tsunamis are generated by intense, low-dispersive and rapid (one with a high rate of air pressure change, e.g., $5 \mathrm{hPa} 10 \mathrm{~min}^{-1}$ ) air pressure disturbances which, as we will show, can be tracked on the ground. Meteorological tsunamis are most likely to be generated when a disturbance is propagating

Published by Copernicus Publications on behalf of the European Geosciences Union. 
towards the coast, and its speed of propagation $u$ equals the speed $c$ of barotropic sea waves $c=\sqrt{g H}$ (where $g$ is the gravity acceleration and $H$ is the water depth). In this case, the air pressure disturbance resonantly transfers energy to long open sea waves (Proudman, 1929). Upon reaching the coast these long sea waves can enhance natural modes of oscillations (seiches) of bays and harbours to destructive heights through harbour resonance (Raichlen, 1966). The question is whether these theoretical considerations can be applied to real atmospheric disturbances and ocean waves in real basins and especially in real time, as a tsunami warning system should have the latency on a minute timescale.

We have been developing the Adriatic Sea meteotsunami research and warning network, and our first aim is to empirically quantify the relation between the characteristics of air pressure disturbances and sea level oscillations. Our second aim is to subsequently create an efficient warning system, based on a real time assessment of the rate of change of air pressure over the region (Šepić et al., 2009a) and other characteristics of meteotsunamis. The network is located at the middle Adriatic where two highly destructive meteotsunamis have occurred in the last 30 years, the 21 June 1978 Vela Luka meteotsunami (Hodžić, 1979/1980) and the 27 June 2003 middle Adriatic meteotsunami (Vilibić et al., 2004).

In this paper, we will present the network and demonstrate how a possible low-cost, low-maintenance meteotsunami warning system consisting of as little as three air pressure measuring units can be constructed. The system has a potential of being adjusted and applied to other world wide locations and added to the existing tsunami warning system.

\section{The Adriatic meteotsunami research and warning network}

\subsection{Present state of the network - pilot phase}

At present, the Adriatic meteotsunami network is in a pilot phase, running continuously since March 2009 and is used solely for research purposes. It comprises of a central processing unit located in Split and three air pressure measuring stations (Fig. 1) located in the middle Adriatic area. There is also a possibility of using sea-level data from permanent tide gauge stations in Zadar, Split, Ploče and Dubrovnik. Air pressure measuring stations are located at the islands of Vis (town of Vis), Korčula (Vela Luka town) and Hvar (town of Vrboska). Towns of Vela Luka on Korčula, Stari Grad (6 km from Vrboska) on Hvar and Mali Ston on the mainland are places where the most destructive Adriatic meteotsunamis have occurred (Vilibić and Šepić, 2009). All air pressure stations are equipped with Vaisala PTB330 high precision microbarographs (precision $\pm 0.01 \mathrm{hPa}$ ), an embedded simple computer which can log data for 30 days and serve as a link between the central unit in Split and an air pressure station, a battery which provides an autonomous

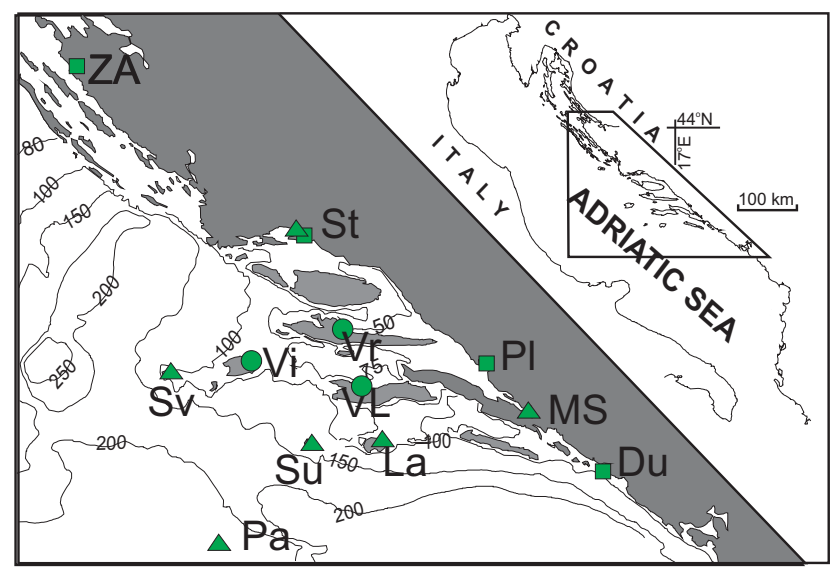

Fig. 1. Bathymetry for the central coastal region Adriatic Sea. Squares mark tide gauge stations: Zadar (Za), Split (St), Ploče (Pl), Dubrovnik (Du). Circles mark microbarograph stations: Vrboska (Vr), Vis (Vi) and Vela Luka (VL). Triangles mark possible future microbarograph stations: Svetac (Sv), Sušac (Su), Palagruža (Pa), Lastovo (La), St and Mali Ston (MS). In the last 30 years, strong meteotsunamis have occurred at Stari Grad (near Vr), Vela Luka (VL) and Mali Ston (MS).

functioning of up to 7 days in a case of electricity failure and with GPRS internet connection. Air pressure is measured each second; data are stored on an embedded computer and sent each hour to a central processing unit in Split where $1 \mathrm{~min}$ averages of data and $5 \mathrm{~min}$ rates of air pressure change are calculated (difference between a pressure measured at a given time and a pressure measured 5 min before the given time). The data and the products are stored in the Institute of Oceanography and Fisheries data base. All measured air pressure data and rates of change of air pressure can be visually inspected online at http://jadran.izor.hr/barograf/ index_eng.htm. The recovery of data in the last year of operation is at least $95 \%$ at any individual station, including the longest loss of data of 10 days at the Vela Luka station due to a prolonged electricity loss.

Intense air pressure disturbances (e.g., ones related to gravity waves and convective jumps) can occur at time scales of $1 \mathrm{~min}$, and our calculation of $5 \mathrm{~min}$ rates of air pressure change, could result in smoothing and even disappearance of some shorter lasting disturbances. However, based on data from the previous Adriatic meteotsunamis, we find that meteotsunamis are generated, not only by intense but also, by longer lasting air pressure disturbances (longer being at least $5 \mathrm{~min}$ ). Three of the four strongest observed meteotsunamis were generated by air pressure disturbances with rates of air pressure change surpassing $1.5 \mathrm{hPa} 5 \mathrm{~min}^{-1}$ : the Stari Grad meteotsunami of 2003 (Vilibić et al., 2004); the Ist meteotsunami of 2007 (Šepić et al., 2009c) and the Mali Lošinj meteotsunami of 2008 (Belušić and Strelec-Mahović, 2009). Analogue air pressure records of the strongest Adriatic meteotsunami, the Vela Luka meteotsunami of 
1978, were not of a sufficient quality to estimate a rate of air pressure change, but Orlić et al. (2010) successfully modelled the event by forcing the sea with an air pressure disturbance having a $1.5 \mathrm{hPa} 5 \mathrm{~min}^{-1}$ rate of air pressure change. Nevertheless, upon obtaining tide gauge data for endangered locations we plan to quantitatively determine the most appropriate period for estimating rates of air pressure change relevant for generation of meteorological tsunamis.

The main shortcoming of the pilot network is a lack of tide gauge stations at the most endangered locations (Vela Luka and Stari Grad). Four tide gauge stations (Zadar, Split, Ploče and Dubrovnik; Fig. 1) which are present in the middle Adriatic area can be used for estimating the influence of air pressure disturbances on sea level. In order to get more precise relations at the most endangered areas, tide gauges will be installed at Stari Grad on the island of Hvar and at Vela Luka on the island of Korčula as soon as funding is obtained.

After it has been fully operational for two years, all data from the network will be processed. Air pressure time series will be examined for distinctive air pressure disturbances, their velocities estimated and the resulting sea responses at vulnerable harbours and at the wider middle Adriatic area determined. The final product of the first part of the project will be a meteotsunami warning matrix relating specific characteristics of air pressure disturbances to the level of a meteotsunami danger. A preliminary matrix has already been established. The preliminary matrix is based on previous meteotsunami events, theoretical estimations, and numerical modelling. Two destructive meteotsunami events have been previously observed at Stari Grad and Vela Luka. The air pressure disturbance which generated the 2003 Stari Grad meteotsunami propagated with a speed of $22 \mathrm{~m} \mathrm{~s}^{-1}$ and a direction of $290^{\circ}$ (Vilibić et al., 2004); and the air pressure disturbance which generated the 1978 Vela Luka meteotsunami propagated with a speed of $22 \mathrm{~m} \mathrm{~s}^{-1}$ and a direction of $238^{\circ}$ (Orlić, 1980). According to the Proudman resonance (Proudman, 1929), the most dangerous meteotsunamis should be generated by an air pressure disturbance propagating towards the entrance of a harbour or a bay resulting in a range of favourable angles of 270 $290^{\circ}$ for Stari Grad and $220-250^{\circ}$ for Vela Luka. The speed $c$ of this disturbance should be equal to the speed $u$ of barotropic ocean waves. As the speed of barotropic ocean waves is a function of sea depth $H(c=\sqrt{g H})$, it follows that air pressure disturbance should propagate with speeds of $21-23 \mathrm{~m} \mathrm{~s}^{-1}$ to generate a strong Stari Grad meteotsunami (corresponding to depths of $45-55 \mathrm{~m}$ found in front of Stari Grad); i.e. with speeds of $32-37 \mathrm{~m} \mathrm{~s}^{-1}$ to generate a strong Vela Luka meteotsunami (corresponding to depths of 100$140 \mathrm{~m}$ found in front of Vela Luka). Finally, results of numerical modelling of meteotsunamis done for Stari Grad by Vilibić et al. (2004) and for Vela Luka by Orlić et al. (2010) also indicate a range of most favourable speeds and directions for both locations and were also taken into account when constructing the warning matrix. Table 1 presents a preliminary warning matrix for Stari Grad and Mali Ston and Table 2 for Vela Luka. It has to be stressed out that this is a preliminary matrix, and that an extensive analysis of simultaneous sea level and air pressure data is still needed to construct an operational matrix. Upon comparing sea level and air pressure data, we also plan to add a column with expected wave height to the warning matrix.

\subsection{Future state of the network - research and warning}

Once all quantitative relations are established, the meteotsunami research network will be transformed into a meteotsunami warning network which will comprise of the same instruments and structure as the pilot network. However, the present configuration of the instruments does not allow for a timely warning. Once a dangerous air pressure disturbance is measured at Vela Luka or Vrboska, a meteotsunami has probably already occurred. This problem can be overcome by moving existing or installing new microbarographs at the islands to the south and west of endangered harbours, in particular at Palagruža, Svetac and Sušac giving a warning lead time of about $15 \mathrm{~min}$. The meteotsunami detection algorithm will then function as follows:

- Air pressure is measured and averaged (30 s averages) at all stations.

- Five min rates of change of air pressure are calculated at stations.

- When an air pressure disturbance with a rate of change surpassing a critical one (preliminary set to $1 \mathrm{hPa} 5 \mathrm{~min}^{-1}$ ) is detected at the Palagruža or Svetac station, a signal is sent from that station to the central unit and from the central unit to the other stations. The Svetac and Palagruža stations are chosen as the trigger ones because any air pressure disturbance with ability to generate a meteorological tsunami at the most endangered middle Adriatic areas will come from the southwest to northwest directions (see Table 1) and will, thus, first be at one of those two stations.

- All stations enter a burst mode and start sending data each second for a predetermined period of time (e.g., 3 h).

- A disturbance tracking and velocity estimation algorithm is applied to incoming data. The algorithm searches for a dangerous disturbance at the other stations in predetermined time intervals which depend on lower and upper ends of possibly dangerous speeds and direction of propagation. For example, in case of Stari Grad meteorological tsunami, a possibly dangerous air pressure disturbance will come to the Vis station 9-38 min, to the Sušac station $18-72 \mathrm{~min}$, to the 
Table 1. Preliminary meteotsunami warning matrix for Stari Grad and Mali Ston.

\begin{tabular}{llll}
\hline $\begin{array}{l}\text { Rate of air pressure change } \\
\left(\mathrm{hPa} 5 \mathrm{~min}^{-1}\right)\end{array}$ & $\begin{array}{l}\text { Velocity } \\
\left(\mathrm{m} \mathrm{s}^{-1}\right)\end{array}$ & $\begin{array}{l}\text { Incoming direction } \\
\left({ }^{\circ}\right)\end{array}$ & Meteotsunami danger \\
\hline$>2.0$ & {$[21-23]$} & {$[270-290]$} & Destructive meteotsunami possible \\
$>2.0$ & {$[21-23]$} & {$[235-270]$ or $[290-325]$} & $\begin{array}{l}\text { Moderate metetosunami possible } \\
>2.0\end{array}$ \\
{$[17-21]$ or $[23-27]$} & {$[270-290]$} & Moderate \\
{$[1.0-2.0]$} & {$[21-23]$} & {$[270-290]$} & Moderate \\
$>2.0$ & {$[17-21]$ or $[23-27]$} & {$[235-270]$ or $[290-325]$} & Weak meteotsuanmi possible \\
{$[1.0-2.0]$} & {$[21-23]$} & {$[235-270]$ or $[290-325]$} & Weak \\
{$[1.0-2.0]$} & {$[17-21]$ or $[23-27]$} & {$[270-290]$} & Weak \\
{$[1.0-2.0]$} & {$[17-21]$ or $[23-27]$} & {$[235-270]$ or $[290-325]$} & Very weak meteotsunami possible \\
$<1.0$ & Any range & Any range & No meteotsunami danger \\
Any range & $<17$ or $>27$ & Any range & No meteotsunami danger \\
Any range & Any range & $<235$ or $>325$ & No meteotsunami danger \\
\hline
\end{tabular}

Table 2. Preliminary meteotsunami warning matrix for Vela Luka.

\begin{tabular}{llll}
\hline $\begin{array}{l}\text { Rate of air pressure change } \\
\left(\mathrm{hPa} 5 \mathrm{~min}^{-1}\right)\end{array}$ & $\begin{array}{l}\text { Velocity } \\
\left(\mathrm{m} \mathrm{s}^{-1}\right)\end{array}$ & $\begin{array}{l}\text { Incoming direction } \\
\left({ }^{\circ}\right)\end{array}$ & Meteotsunami danger \\
\hline$>2.0$ & {$[32-37]$} & {$[200-250]$} & \\
$>2.0$ & {$[32-37]$} & {$[180-200]$ or $[250-270]$} & $\begin{array}{l}\text { Destructive meteotsunami possible } \\
\text { Moderate metetosunami possible }\end{array}$ \\
$>2.0$ & {$[22-32]$ or [37-40] } & {$[200-250]$} & Moderate \\
{$[1.0-2.0]$} & {$[32-37]$} & {$[200-250]$} & Moderate \\
$>2.0$ & {$[22-32]$ or $[37-40]$} & {$[180-200]$ or $[250-270]$} & Weak meteotsuanmi possible \\
{$[1.0-2.0]$} & {$[32-37]$} & {$[180-200]$ or $[250-270]$} & Weak \\
{$[1.0-2.0]$} & {$[22-32]$ or $[37-40]$} & {$[200-250]$} & Weak \\
{$[1.0-2.0]$} & {$[22-32]$ or $[37-40]$} & {$[180-200]$ or $[250-270]$} & Very weak meteotsunami possible \\
$<1.0$ & Any range & Any range & No meteotsunami danger \\
Any range & $<22$ or $>40$ & Any range & No meteotsunami danger \\
Any range & Any range & $<180$ or $>270$ & No meteotsunami danger \\
\hline
\end{tabular}

Vela Luka station 30-70 min and to the Vrboska station 15-85 min after observed at the Svetac station. Large range of travel times at any individual station is due to a large range of favourable speeds and directions of air pressure disturbances. Arrival times are calculated for disturbances propagating with all speeds and directions listed in a meteotsunami warning matrix (Table 1; e.g., speeds of $17-27 \mathrm{~m} \mathrm{~s}^{-1}$, and directions of $230-325^{\circ}$ for Stari Grad). Minimum and maximum of these travel times at any individual station represent ranges of travel times for that station.

- If the disturbance is detected at any other two stations in predetermined time intervals, speed and direction of the disturbance are automatically calculated with an algorithm described by Šepić et al. (2009a) and repeated in Appendix A of this paper. When a disturbance is detected at more than three stations, its speed and direction can be estimated with the least square method (e.g., Orlić, 1980).

- Velocity of the disturbance is compared to values given in a meteotsunami decision matrix and appropriate warning is issued (Tables 1 and 2).

Next, we will try to demonstrate applicability of a future warning system on two real cases.

\section{Testing the meteotsunami network}

\subsection{The event of 19 February 2010}

Stari Grad on the island of Hvar (Fig. 1) was struck by a meteorological tsunami around 14:00 UTC on 19 February 2010. When the meteotsunami hit, the sea level was already extremely high due to a storm surge generated by a low pressure system and associated winds. The low pressure 


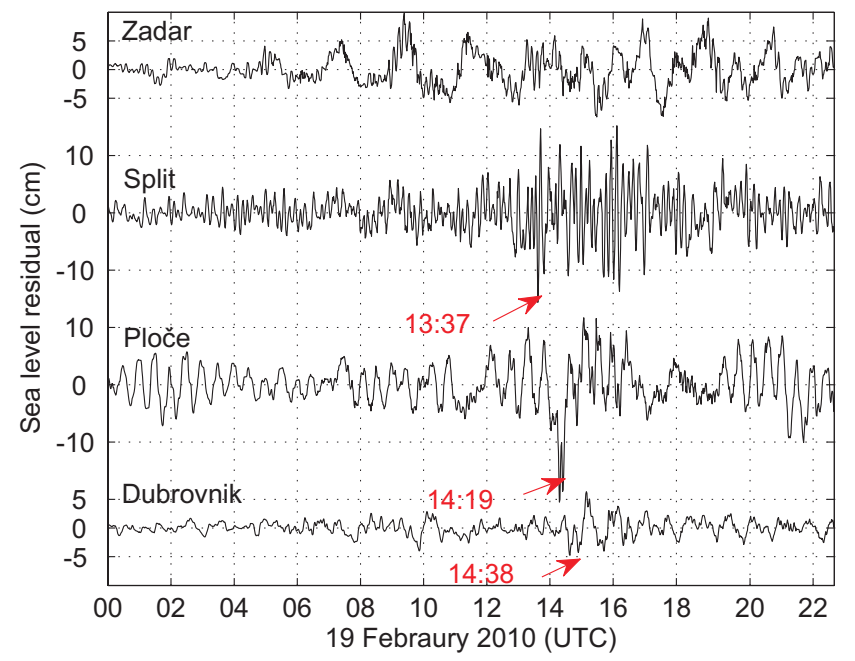

Fig. 2. Sea level time series for Zadar, Split, Ploče and Dubrovnik. Series have been filtered with a 3-h Keiser-Bessel filter. Red arrows indicate the arrival time of the first meteotsunami-related sea wave at the stations.

system was centred over the Atlantic just to the west of the French coast, but encompassed most of Europe, including the Adriatic Sea. During the meteotsunami, the sea level suddenly rose and flowed over the town's promenade, rising above it by approximately $30 \mathrm{~cm}$. Although the sea level rise was not particularly high, associated currents were strong enough to pull one car and several large garbage containers into the sea (newspaper reports).

Stronger than usual sea level oscillations were recorded at permanent tide gauge stations at Split, Ploče and Dubrovnik (Fig. 2) near the time of the meteotsunami. Further to the north, the Zadar tide gauge station recorded no oscillations which could, with certainty, be associated with the meteotsunami. Sea level oscillations at the southern tide gauge stations started with the arrival of a distinct wave which had a height of $30 \mathrm{~cm}$ at Split, $25 \mathrm{~cm}$ at Ploče and $10 \mathrm{~cm}$ at Dubrovnik. The wave first arrived at Split at 13:37 UTC, then 41 minutes later at Ploče and another $36 \mathrm{~min}$ later at Dubrovnik. Although the travel time of the waves and the distances among the stations are known, it is not possible to use the data to determine the velocity of sea waves. This is because the three tide gauge stations are in a line, whereas a triangular configuration of stations is needed for the determination of velocity and direction. After the first wave, sea level oscillations continued in Split and Ploče, two harbours prone to seiches, for several hours.

Air pressure time series from the three microbarograph stations (Vis, Vela Luka, and Vrboska) show a sudden air pressure drop of approximately $2.5 \mathrm{hPa}$ between 13:00 and 14:00 UTC (Fig. 3a). Note that observed sea level oscillations in Split were $30 \mathrm{~cm}$, more than 12 times higher than expected only from inverted barometer effect. The air pressure disturbance was first measured at Vis, then
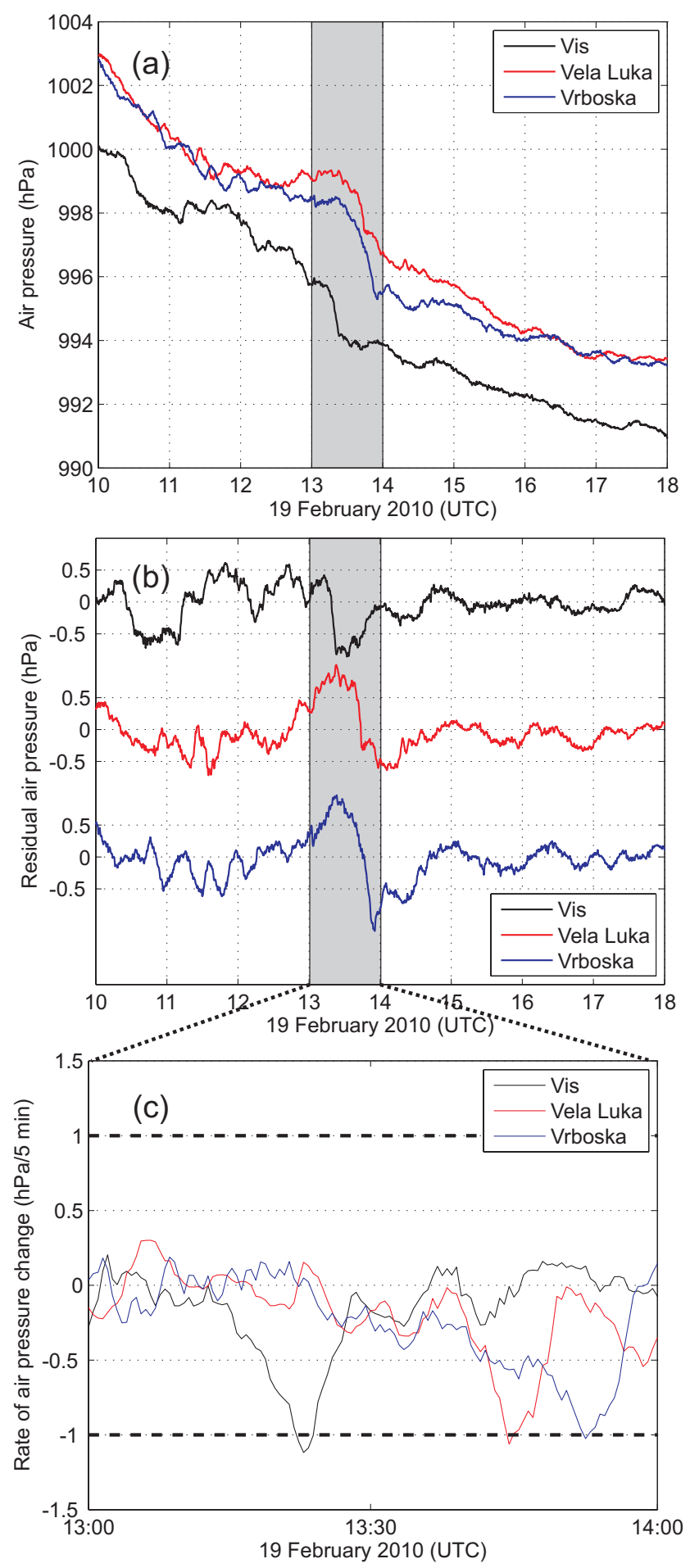

Fig. 3. (a) Air pressure records for the 19 February 2010 meteotsunami event, (b) residual records (after filtering with a 3-h Kaiser-Bessel filter); shaded areas in (a) and (b) show the atmospheric disturbance, and (c) 5-min rates of air pressure change. Dashed lines denote the 5-min rate of air pressure change threshold $\left(1 \mathrm{hPa} 5 \mathrm{~min}^{-1}\right)$. 
at Vela Luka and finally at Vrboska. The 5 min rates of change of air pressure from the three stations were put into the disturbance tracking and velocity estimation algorithm. The disturbance had an estimated speed of 22 to $23 \mathrm{~m} \mathrm{~s}^{-1}$ and direction of $235^{\circ}$, so that the disturbance was roughly moving toward the northeast, and was recognized as an event during which a weak meteotsunami was possible (Table 1). A velocity of $22-23 \mathrm{~m} \mathrm{~s}^{-1}$ was also previously reported for the 2003 middle Adriatic meteotsunami (Vilibić et al., 2004). The February 2010 rate of air pressure change of $\sim 1.0 \mathrm{hPa} 5 \mathrm{~min}^{-1}$ is considered strong enough to generate a meteotsunami, but not a highly destructive one (the destructive meteotsunami that impacted Stari Grad in 2003 was generated by an air pressure disturbance with a rate of air pressure change surpassing $2 \mathrm{hPa} 5 \mathrm{~min}^{-1}$; Vilibić et al., 2004). The direction of $235^{\circ}$ is at the lower end of meteotsunami favourable directions for Stari Grad, as determined by numerical modelling (directions of 230 to $310^{\circ}$, Vilibić et al., 2004), and, together with the lower rate of air pressure change, there might be a reason why the 2010 meteotsunami was not very pronounced. Again, the destructive 2003 meteotsunami had an incoming direction of $290^{\circ}$, which together with the rate of air pressure change higher than $2 \mathrm{hPa} 5 \mathrm{~min}^{-1}$ and speed of 22-23 $\mathrm{m} \mathrm{s}-1$, raises the meteotsunami warning to a "destructive meteotsunami possible" (Table 1).

\subsection{The event of 27-28 May 2009}

Aside from the event described above, during almost one and a half years of air pressure measurements, there were no other meteotsunamis reported in the middle Adriatic area. However, inspection of microbarograph data revealed that, at several more instances, strong air pressure oscillations were measured. On the most of these occasions air pressure oscillations were not measured at all stations indicating that disturbances were either short-lived or had limited spatial dimensions. We have found only one other occasion during which an intense air pressure disturbance was observed at all stations, but this time no meteotsunami was reported.

On the night of 27-28 May 2009 between 23:00 and 01:00 UTC, intense air pressure oscillations were observed at all microbarographs stations (Fig. 4). The disturbance consisted of a sudden air pressure rise followed by an air pressure drop and several weaker oscillations varying in intensity and duration between different stations. The rate of air pressure change was much higher than during the 19 February 2010 event and on two stations even surpassed $2 \mathrm{hPa} 5 \mathrm{~min}^{-1}$. We input time series into the algorithm and obtained a velocity estimation of $21-24 \mathrm{~m} \mathrm{~s}^{-1}$ and $243-276^{\circ}$. These values are associated with a danger of a weak or even a moderate meteotsunami at Stari Grad and of a very weak meteotsunami at Vela Luka (Tables 1 and 2). However, no noticeable event was reported. When comparing two air pressure disturbances, the February 2010 one had a
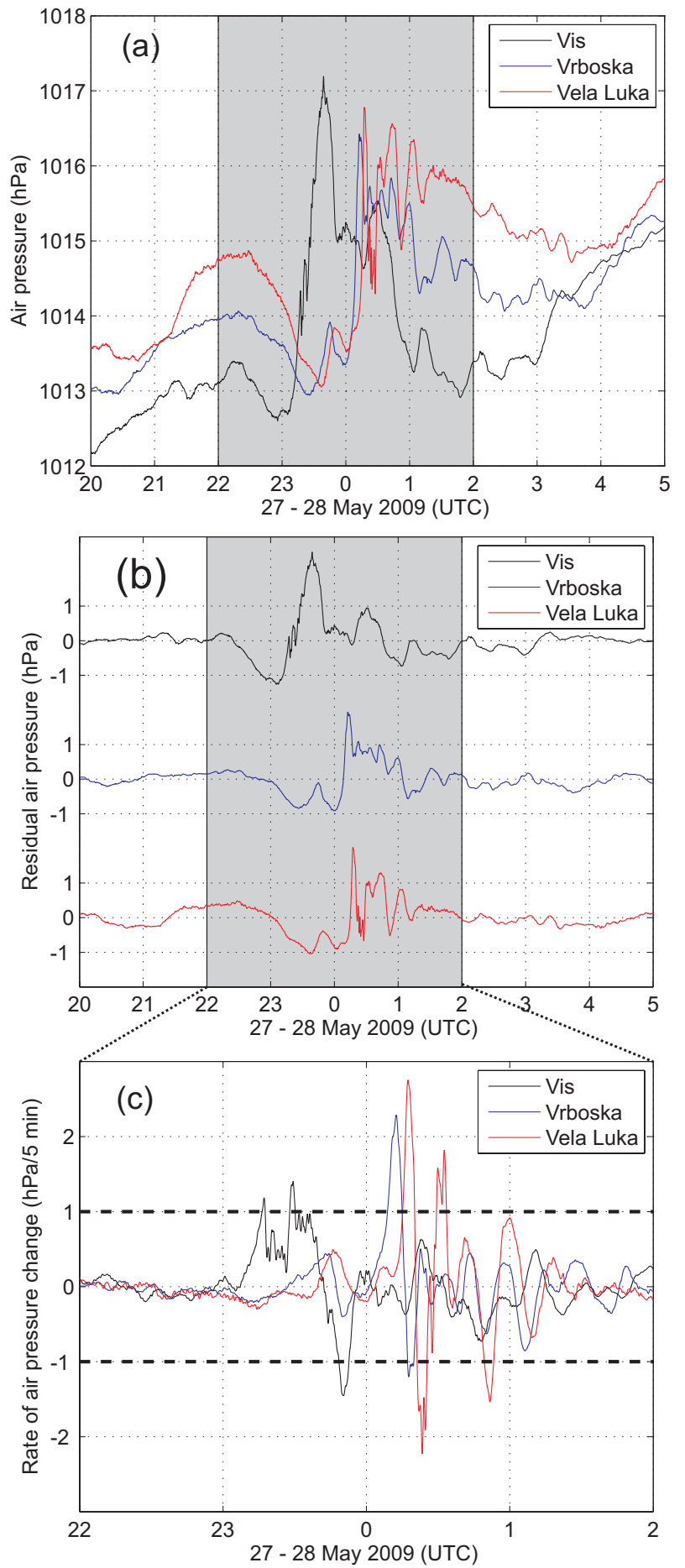

Fig. 4. Same as Fig. 3, but for the 27-28 May 2009 event.

very similar shape at all stations, while the May 2009 one, although stronger in intensity, was much more dispersive: it changed significantly between the first and the other two stations, and reached its maximum intensity only upon reaching the coast. It is possible that the disturbance was even weaker before reaching Vis and that it did not have 


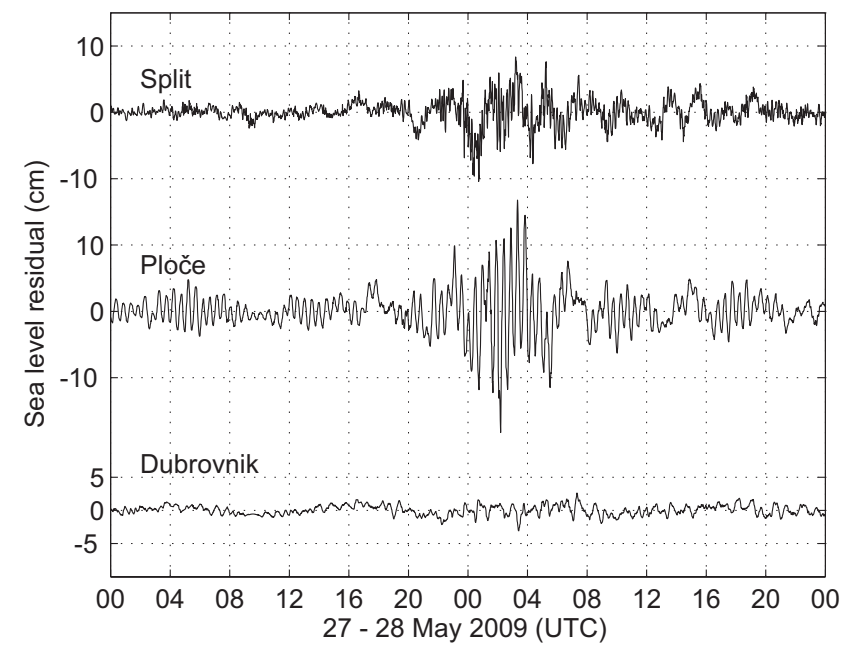

Fig. 5. Sea level time series for Split, Ploče and Dubrovnik. Series have been filtered with a 3-h Keiser-Bessel filter.

sufficient time to create long waves at the open sea. The strongest meteotsunamis in the Adriatic Sea, the 1978 Vela Luka (Orlić et al., 2010), the 2003 Stari Grad (Vilibić at al., 2004) and the 2007 Ist meteotsunami (Šepić et al., 2009c) have all been created by air pressure disturbances not changing significantly while travelling over at least $80 \mathrm{~km}$ of open sea.

Nonetheless, tide gauges in Split and Ploče revealed pronounced sea level oscillations with maximum height of $12 \mathrm{~cm}$ at Split and $30 \mathrm{~cm}$ at Ploče, around 00:00 UTC on 28 May 2009 (Fig. 5). No significant oscillations were noticed at Dubrovnik. The fact that oscillations were strongest at Ploče also indicated that the air pressure disturbance might have grown in strength as it propagated eastward. There is also a possibility that sea level oscillations were present at the endangered middle Adriatic stations, but that they were not noticed due to a number of reasons: mean sea level on 27-29 May 2009 and a few surrounding days was $\sim 30 \mathrm{~cm}$ lower than sea level on 18-20 February 2010 (according to tide-gauge in Split); the May 2009 air pressure disturbance crossed the area during a low tide, while the February 2010 tide occurred during the sea level rise (adding additional $15 \mathrm{~cm}$ to difference between sea levels at two dates); and finally the May disturbance occurred in the middle of the night, reducing the possibility for observation. If the sea level during the February 2010 meteotsunami was not already extremely high due to a storm surge, sea water would probably not have inundated Stari Grad and no damage would have been reported.

\section{Conclusions and discussion}

We have created a simple and a low cost meteotsunami research network with an intention to upgrade it to an operational warning network after extensive measurements have been completed. At present, only the meteorological service of the Balearic Islands issues meteotsunami warnings (Jansa et al., 2007). But since they are based solely on presence of meteotsunami favourable synoptic conditions, they lack information on strength of a meteotsunami; and, when a devastating meteotsunami like the one of 15 June 2006 does happen, induced damage can be enormous in spite of the warning issued (Jansa et al., 2007). There is now an attempt to create a more reliable meteotsunami warning network for the Balearic Islands (Marcos et al., 2009). As opposed to ours, the Balearic network is based more on analysis of sea level oscillations at different locations than on analysis of air pressure data. The assumption is: if a "beacon" harbour far enough from an endangered harbour observes strong sea level oscillation, then similar but even stronger oscillation can be expected at endangered harbours prone to destructive meteotsunamis. On the other hand, we place a main focus of the Adriatic meteotsunami warning system on air pressure measurements.

We have demonstrated the ability of the Adriatic network to forecast meteotsunamis solely from air pressure measurements (the Stari Grad meteotsunami of the February 2010). However, there was one more event of significant air pressure oscillations during one and half years of measurements which our system recognized as possibly dangerous but no meteotsunami was observed. This is not a discouraging result as even high-cost tsunami warning systems sometimes overestimate tsunami danger as was the case with the 2010 Chilean tsunami when the Pacific Tsunami Warning Centre (PTWC) and West Coast/Alaska Tsunami Warning Centre (WC/ATWC) issued tsunami warning and advisories for a number of Pacific regions at which no destructive tsunami was observed (reports available at: http://ioc3.unesco.org/itic/).

We have tried to answer why one of the observed air pressure disturbances at the Adriatic generated a meteotsunami and created damage, and the second one did not. We conclude that a dispersion of air pressure disturbance and a mean sea level preceding a meteotsunami could both be important factors when assessing a meteotsunami danger and their estimation should be added to a tsunami warning system. Mean sea level can be an important parameter since the Adriatic harbours are not constructed to withstand large sea level oscillation. Tidal range at the middle Adriatic is $\sim 20 \mathrm{~cm}$ (Cushman-Roisin et al., 2001) and, thus, even sea level oscillations of smaller amplitudes (e.g. several tens of $\mathrm{cm}$ ) can provoke damage if they occur when mean sea level is high.

When additional microbarographs are placed to the west and south of endangered areas (Fig. 1) the network will be able to issue a warning 11-18 min before an air pressure disturbance with a velocity value favourable for generation of destructive meteotsunamis in Vela Luka (as defined in a meteotsunami warning matrix) arrives there, and $18-25 \mathrm{~min}$ before a disturbance most dangerous for Stari Grad arrives 
there. We are aware that this is a short time. But, given a good organization of civil services, this time should be enough to warn people to get out from the sea and off the beaches and immediate coast and thus protect their lives, especially as meteotsunamis in the Adriatic mostly occur in summer months when beaches are crowded (Vilibić and Šepić, 2009). The most appropriate way of issuing a short-notice meteotsunami warning would be to connect our warning system with national mobile phone companies which could, in a case of an alarm, send a warning message to all mobiles phones registered at a specific transmitter. For some protective actions, like moving the boats from the harbour to the open sea, a warning lead time of about $15 \mathrm{~min}$ is not enough. A warning lead time could however be increased by placing microbarographs to oceanographic buoys placed further away from endangered harbours and available islands. This would allow for an earlier observation of an air pressure disturbance and thus for an earlier warning. Microbarographs could also be attached to oceanographic buoys at other World locations which lack islands.

The probability for a timely preliminary warning can be increased in a few more ways. Meteotsunami generating air pressure disturbances at the Mediterranean usually propagate only under specific conditions (Jansa et al., 2009; Šepić et al., 2009b), and usually following the direction and speed of wind at a height of an unstable atmospheric layer (characterised by values of Richardson number $<0.25$, and commonly found at heights of about $5000 \mathrm{~m}$; e.g., Monserrat and Thorpe, 1992; Šepić et al., 2009c). The same was true for the first event described in this paper. Upper air sounding data from Zadar at 12:00 UTC 19 February 2010 reveal that wind at the bottom of an atmospheric layer with the lowest stability (between 6000 and $7000 \mathrm{~m}$ ) had a speed of $22 \mathrm{~m} \mathrm{~s}^{-1}$ and a south-westerly direction (agreeing well with the estimated speed and direction of the air pressure disturbance that forced the Stari Grad meteotsunami). Zadar sounding data from 28 May 2010 at 00:00 UTC show that there was an unstable atmospheric layer between 3000 and $4000 \mathrm{~m}$. Wind at this layer had a speed of $20 \mathrm{~m} \mathrm{~s}^{-1}$, thus, close to estimated speed of the air pressure disturbance; but wind also had a southerly direction, not corresponding so well with estimated direction of propagation of the disturbance. Difference between wind direction at unstable layer and direction of propagation of the disturbance might have been related to dispersive nature of the disturbance. Data from upper air soundings, which is freely available in real-time at http://weather.uwyo.edu/upperair/sounding. html, can be easily implemented to a meteotsunami warning system. Once a dangerous disturbance is observed at the first station (Svetac), if the wind speed and direction at upper unstable atmospheric layers and synoptic conditions are meteotsunami favourable, a reliable warning might be issued 26-38 min before the most dangerous disturbances reach Vela Luka, and 40-53 min before the most dangerous disturbances reach Stari Grad. Existing air pressure measurements, upper air soundings and analysis of synoptic conditions should be enough to examine this relation, and we will do it in our future work.

Belušić and Strelec Mahović (2009) discuss additional possibilities for a meteotsunami warning system. Often, especially in the Adriatic Sea, meteorological tsunamis are related to convective clouds. It is possible to detect these clouds via meteorological satellites in real time and to estimate their propagation speed and direction, and thus, again by combining this information with air pressure measurements, issue a timely warning. It is our belief that based on all these data, once an extensive set of measurements is obtained, we will be able to create a highly efficient low-cost meteotsunami warning system which could then be further adjusted and applied to other world locations.

\section{Appendix A}

The speed $U$ and direction $\alpha$ (measured clockwise from the northward direction toward the direction of propagation) of a travelling atmospheric disturbance based on observations on a triangular array of microbarographs with coordinates $\left(x_{1}, y_{1}\right),\left(x_{2}, y_{2}\right)$ and $\left(x_{3}, y_{3}\right)$ is estimated by applying the following assumptions: (i) the disturbance does not change during its travel over the domain (it propagates as a plane wave), and (ii) the disturbance has a constant speed $C$ and a direction $\alpha$. Simple plane geometry yields the following expressions:

$$
\begin{aligned}
& \tan \alpha=a=\frac{t_{1,2} d y_{1,3}-t_{1,3} d y_{1,2}}{t_{1,3} d x_{1,2}-t_{1,2} d x_{1,3}} \\
& C=\frac{1}{t_{1,2}} \frac{d y_{1,2}+a \cdot d x_{1,2}}{\sqrt{1+a^{2}}}=\frac{1}{t_{1,3}} \frac{d y_{1,3}+a \cdot d x_{1,3}}{\sqrt{1+a^{2}}},
\end{aligned}
$$

where $d y_{1,2}, d x_{1,2}, d y_{1,3}$, and $d x_{1,3}$ are distances between stations 1 and 2 and between stations 1 and 3 in the northsouth and east-west direction, respectively; $t_{1,2}$ and $t_{1,3}$ are measured time lags of a threshold-exceeding rates of change of air pressure between stations 2 and 3 and station 1 .

Acknowledgements. The sea level data for Croatia was obtained from the Hydrographic Institute of the Republic of Croatia. We thank to Stipe Muslim, Damir Ivanković and Siniša Marasović who have been strongly engaged in creation, development and maintenance of the meteotsunami network. We also kindly thank Paul Whitmore and another anonymous referee for their valuable comments. The work was supported by the Ministry of Science, Education and Sports of the Republic of Croatia (research grant 001-0013077-1122 and IT grant IP-OCEAN).

Edited by: S. Monserrat

Reviewed by: P. Whitmore and another anonymous referee 


\section{References}

Bedosti, B.: Considerazioni sul maremoto adriatico (tsunami) del 21.6.1978, Supplemento Bollettini Sismici Provv., 12-14-20, 2 17, 1980 (in Italian).

Belušić, D., and Strelec Mahović, N.: Detecting and following atmospheric disturbances with a potential to generate meteotsunamis in the Adriatic, Phys. Chem. Earth, 34, 918-927, 2009.

Cushman-Roisin, B., Malačić, V., and Gačić, M.: Tides, seiches and low-frequency oscillations, in: Physical oceanography of the Adriatic Sea, edited by: Cushman-Roisin, B., Gačić, M., Poulain, P.-M., and Artegiani, A., Kluwer Academic Publishers, Dordrecht/Boston/London, 217-240, 2001.

Haslett, S. K., Mellor, H. E., and Bryant, E. A.: Meteo-tsunami hazard associated with summer thunderstorms in the United Kingdom, Phys. Chem. Earth, 34, 1016-1022, 2009.

Hibiya, T. and Kajiura, K.: Origin of the Abiki phenomenon (a kind of seiche) in Nagasaki Bay, Journal of the Oceanographical Society of Japan, 38, 172-182, 1982.

Hodžić, M.: Occurences of exceptional sea-level oscillations (seiches) in the Vela Luka Bay, Priroda, 68, 52-53, 1979/1980 (in Croatian).

Jansa, A., Monserrat, S., and Gomis, D.: The rissaga of 15 June 2006 in Ciutadella (Menorca), a meteorological tsunami, Adv. Geosci., 12, 1-4, doi:10.5194/adgeo-12-1-2007, 2007.

Lay, T., Kanamori, H., Ammon, C. J., Nettles, M., Ward, S. N., Aster, R. C., Beck, S. L., Bilek, S. L., Brudzinski, M. R., Butler, R., DeShon, H. R., Ekström, G., Satake, K., and Sipkin, S.: The great Sumatra-Andaman earthquake of 26 December 2004, Science, 308, 1127-1133, 2005.

Marcos, M., Monserrat, S., Medina, R., Orfila, A., and Olabarrieta, M.: External forcing of meteorological tsunamis at the coast of the Balearic Islands, Phys. Chem. Earth, 34, 971-988, 2009.

Meinig, C., Stalin, S. E., Nakamura, A. I., González, F., and Milburn, H. G.: Technology developments in real-time tsunami measuring, monitoring and forecasting, in: Oceans 2005 MTS/IEEE, Washington DC, 7 pp., 19-23 September 2005.

Monserrat, S. and Thorpe, A. J.: Gravity-wave observation using an array of microbarographs in the Balearic Islands, Q. J. Roy. Meteor. Soc., 118, 259-282, 1992.

Monserrat, S., Vilibić, I., and Rabinovich, A. B.: Meteotsunamis: atmospherically induced destructive ocean waves in the tsunami frequency band, Nat. Hazards Earth Syst. Sci., 6, 1035-1051, doi:10.5194/nhess-6-1035-2006, 2006.

Orlić, M.: About a possible occurrence of the Proudman resonance in the Adriatic, Thalassia Jugoslavica, 16, 79-88, 1980.

Orlić, M., Belušić, D., Janeković, I., and Pasarić, M.: Fresh evidence relating the great Adriatic surge of 21 June 1978 to mesoscale atmospheric forcing, J. Geophys. Res., 115, C06011, doi:10.1029/2009JC005777, 2010.

Paxton, C. H. and Sobien, D. A.: Resonant interaction between an atmospheric gravity wave and shallow water wave along Florida's west coast, B. Am. Meteorol. Soc., 79, 2727-2732, 1998.
Proudman, J.: The effects on the sea of changes in atmospheric pressure, Geophys. J. Int., 2, 197-209, 1929.

Raichlen, F.: Harbor resonance, in: Estuary and Coastline Hydrodynamics, edited by: Ippen, A. T., McGraw Hill Book Comp., New York, 281-340, 1966.

Ranguelov, B., Tinti, S., Pagnoni, R., Tonini, R., Zaniboni, F., and Armigliato, A.: The nonseismic tsunami observed in the Bulgarian Black Sea on 7 May 2007: Was it due to a submarine landslide?, Geophys. Res. Lett., 35, L18613, doi:10.1029/2008GL034905, 2008.

Šepić, J., Denis, L., and Vilibić, I.: Real-time procedure for detection of a meteotsunami within an early tsunami warning system, Phys. Chem. Earth, 34, 1023-1031, 2009a.

Šepić, J., Vilibić, I., and Monserrat, S.: Teleconnections between the Adriatic and the Balearic meteotsunamis, Phys. Chem. Earth, 34, 928-937, 2009b.

Šepić, J., Vilibić, I., and Belušić, D.: The source of the 2007 Ist meteotsunami (Adriatic Sea), J. Geophys. Res., 114, C03016, doi:10.1029/2008JC005092, 2009c.

Thomson, R. E., Rabinovich, A. B., Fine, I. V., Sinnott, D. C., McCarthy, A., Sutherland, N. A. S., and Neil, L. K.: Meteorological tsunamis on the coasts of British Columbia and Washington, Phys. Chem. Earth, 34, 971-988, 2009.

Tinti, S., Maramai, A., and Graziani, L.: The new catalogue of the Italian tsunamis, Nat. Hazards, 33, 439-465, 2004.

Titov, V. V., González, F. I., Bernard, E. N., Eble, M. C., Mofjeld, H. O., Newman, J. C., and Venturato, A. J.: Real-time tsunami forecasting: Challenges and solutions, Nat. Hazards, 35, 41-58, 2005.

Vilibić, I. and Šepić, J.: Destructive meteotsunamis along the eastern Adriatic coast: Overview, Phys. Chem. Earth, 34, 904 917, 2009.

Vilibić, I., Domijan, N., Orlić, M., Leder, N., and Pasarić, M.: Resonant coupling of a travelling air pressure disturbance with the east Adriatic coastal waters, J. Geophys. Res., 109, C10001, doi:10.1029/2004JC002279, 2004.

Vilibić, I., Monserrat, S., Rabinovich, A. B., and Mihanović, H.: Numerical modelling of the destructive meteotsunami of 15 June, 2006 on the coast of the Balearic Islands, Pure Appl. Geophys., 165, 2169-2195, 2008.

Vilibić, I., Šepić, J., Ranguelov, B., Strelec Mahović, N., and Tinti, S.: Possible atmospheric origin of the 7 May 2007 western Black Sea shelf tsunami event, J. Geophys. Res., 115, C07006, doi:10.1029/2009JC005904, 2010.

Vučetić, T., Vilibić, I., Tinti, S., and Maramai, A.: The Great Adriatic flood of 21 June 1978 revisited: An overview of the reports, Phys. Chem. Earth, 34, 894-903, 2009.

Wang, X., Li, K., Zhouwen, Y., and Wu, J.: Statistical characteristics of seiches in Longkou Harbor, J. Phys. Oceanogr., 17, 1063-1065, 1987.

Zore-Armanda, M.: Destructive wave in the Adriatic, Rapport et Procesverbaux des Réuninons du Conseil International pour l'Exploration Scientifique de la Mer Méditerranée, 25-26, $93-$ 44, 1979 (in French). 